\begin{tabular}{l|c|c}
\hline ISSN: 0001-5113 & ACTA ADRIAT., & ORIGINAL SCIENTIFIC PAPER \\
AADRAY & 58(1): 53 - 62, 2017 & \\
\hline
\end{tabular}

\title{
Unusual bloom of tetrasporophytes of the non-indigenous red alga Asparagopsis armata in the northern Adriatic Sea
}

\author{
Martina ORLANDO-BONACA*, Borut MAVRIČ, Domen TRKOV and Lovrenc LIPEJ \\ Marine Biology Station, National Institute of Biology, Fornače 41, 6330 Piran,Slovenia \\ "Corresponding author, e-mail: Martina.Orlando@nib.si
}

The tetrasporophyte of the non-indigenous red alga Asparagopsis armata (the Falkenbergia stage) is considered to be established in Slovenian coastal waters. However, until 2016, it was found only in low coverage and in few localities with hard substrata. The paper reports a recent bloom of these tetrasporophytes in the mediolittoral belt of the Bay of Piran, where thalli of this red alga overgrew the articularted coralline alga Corallina officinalis. The sites affected by this large expansion of tetrasporophytes of A. armata should be regularly monitored in the future, in order to point out which environmental factors are responsible for such phenomenon, and to formulate proper conclusions on the status of this non-indigenous alga in the coastal area concerned.

Key words: non-indigenous species; Asparagopsis armata; tetrasporophyte; outburst; northern Adriatic Sea

\section{INTRODUCTION}

The introduction and spreading of non-indigenous (NIS) macrophytes in the Mediterranean Sea were quite well reviewed in the last decades (VERLAQUE, 2001; BOUDOURESQUE \& VERLAQUE, 2002; RIBERA-SIGUAN, 2002; TSIAMIS et al., 2008; GALIL, 2009; TSIAMIS et al. 2013; CORSINI-FOKA et al., 2015; VERLAQUE et al., 2015). Nowadays, the Mediterranean and the NE Atlantic are known to support the highest number of macrophytes introductions in the world (PACIOS et al., 2011). The main vectors of this process are confirmed to be maritime traffic (hull fouling, ballast waters and sediments in ballast tanks, sediments attached to anchors/chains, commercial fishing gear), aquaculture (GOLLASCH \& LEPPÄKOSKI, 1999; RILOV \& CROOKS, 2009; MICAEL et al., 2014), aquarium trade and exchange (STAM et al., 2006), and through the Suez Canal in the Mediterrane- an Sea since 1869 (GALIL et al., 2014). Some NIS macrophytes are defined as invasive. According to the definition of the EUROPEAN COMMISSION (2002), invasive are those NIS "whose introduction and/or spread outside their natural past or present distribution threaten biological diversity". They may have a negative impact not only on local biodiversity (displacing native species, changing community structure and modifying habitats), but also on human health, ecosystem services, and local economies (KATSANEVAKIS et al., 2014).

Two species of the tropical/temperate red algal genus Asparagopsis Montagne (order Bonnemaisoniales), A. armata Harvey and A. taxiformis (Delile) Trevisan de Saint-Léon, include populations that have been introduced in the Mediterranean Sea (BOUdOURESQUE \& VERLAQUE, 2002). However, for A. taxiformis, only the lineage 2 is confirmed to have an Indo- 
Pacific origin and it is considered invasive (ANDREAKIS et al, 2009). On the contrary, the lineage 3 of $A$. taxiformis, with the type specimen collected in Alexandria (Egypt) well before the opening of the Suez Canal, is supposed to have an Atlantic-Mediterranean origin (ANDREAKIS et al, 2009).

The diploid epiphytic tetrasporophyte of the genus Asparagopsis is known as the 'Falkenbergia' stage, small "pompon" naturally occurring as epiphyte, sometimes as a free floating thallus deriving from detachment (CHIHARA, 1961). Both mentioned Asparagopsis species are present in the southern Adriatic Sea (MAČIĆ et al., 2014), while in the northern and central Adriatic only A. armata was found up to date (ANTOLIĆ et al., 2013).

A. armata is a temperate species, native to New Zealand and southern Australia (HORRIDGE, 1951; BONIN \& HAWKES, 1987). In the North Atlantic, it can be found in coastal waters ranging from the British Isles to the Canary Islands, as well as from Salvage Islands to the Senegal coasts (DIXON \& IRVINE, 1977; PRICE et al., 1986). The known temperature tolerance data indicate that it naturally occupies cold to warm temperate zones (NÍ CHUALÁIN et al., 2004). In the Mediterranean Sea, A. armata was firstly reported from the Algerian coast in 1923 (FELDMANN \& FELDMANN, 1942), and it is currently considered as invasive (BOUDOURESQUE \& VERLAQUE, 2002). Its gametophytes are regularly found mostly in the western Mediterranean basin (SOUTH \& TITTLEY, 1986; GUIRY \& DAWES, 1992; SALA \& BOUDOURESQUE, 1997; VERLAQUE et al., 2015). Due to morphological difference, the tetrasporophyte of $A$. armata was originally believed to be a separate species from the gametophyte and was incorrectly classified as F. rufolanosa (Harvey) Schmitz (FELDMANN \& FELDMANN, 1942). It is reported to occur in subtidal communities all year around, primarily as an epiphyte, mostly from late winter to spring (VERLAQUE et al., 2015).

Nowadays, the tetrasporophyte of $A$. armata is considered to be established in Slovenian coastal waters, while the gametophyte has never been found (LIPEJ et al., 2012). However, until now, it was found only at few sites with hard substrata and in low coverage (BATTELLI, 2000; ORLANDO-BONACA, 2001, 2010; ORLANDOBONACA et al., 2016), and it didn't show any negative impacts on native species and habitats (ORLANDO-BONACA et al., 2012).

The aim of this paper is to report a recent bloom of tetrasporophytes of $A$. armata on hard bottom segments along the Slovenian coastline, and to discuss the possible reasons for this extensive coverage in shallow waters, previously never recorded.

\section{MATERIAL AND METHODS}

\section{Study area}

The Bay of Piran is the SW part of the Slovenian Sea, which is a part of the Gulf of Trieste, a shallow semi-enclosed embayment situated in the northernmost part of the Adriatic Sea, extending from Cape Savudrija (Croatia) to Grado (Italy). Although the sea-bed of the Slovenian sea is predominantly soft sedimentary of fluvial origin, the bottom along the coastline (approximately $46.7 \mathrm{~km}$ ) is mostly rocky, consisting mainly of Eocene Flysch layers, with alternating solid sandstone and soft marl (OGORELEC et al., 1997).

\section{Fieldwork and laboratory work}

In October 2016, visual surveys of benthic habitat types were performed by SCUBA diving on $50 \mathrm{~m}$ long transects parallel to the coast, in the mediolittoral and upper-infralittoral belts in front of the town of Piran (Fig. 1, sampling site A). In addition, a sampling frame $(20 \mathrm{~cm} \times 20$ $\mathrm{cm}$ ) was placed on the surface at different depths ( $1 \mathrm{~m}, 2 \mathrm{~m}, 3 \mathrm{~m})$. Quantitative sampling was performed by carefully scraping all algae within the sampling frame and placing the material into collecting bags.

The biological material was then transported to laboratory of the Marine Biology Station of the National Institute of Biology for analysis. Each sample was fixed in $4 \%$ formaldehyde solution. Identification of macroalgal species 


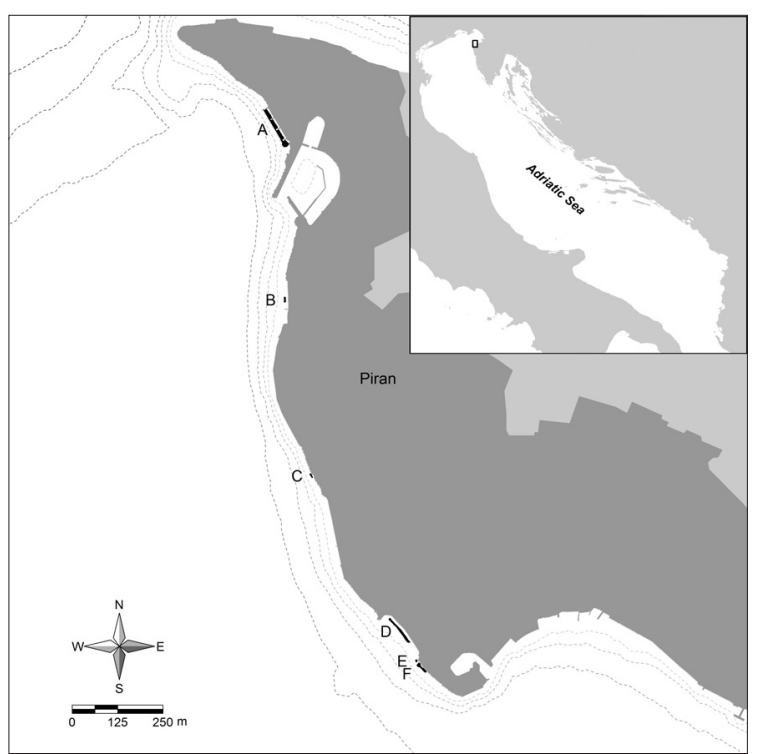

Fig. 1. Map with coastal segments densely covered by tetrasporophytes of $A$. armata in the Bay of Piran

was carried out by using a stereomicroscope Olympus SZH-ILLK, and a microscope Olympus BX51. A set of useful diagnostic characters reported in ZANOLLA et al. (2014) was checked in order to discriminate between tetrasporophytes of A. armata and A. taxiformis. Their findings contradicted previous observations reporting that the tetrasporophyte stages of these species were morphologically identical (ANDREAKIS \& SCHAFFELKE, 2012), since they can be clearly distinguished by the dimensions of the axial cells and the width of the apical cell (ZANOLLA et al., 2014).

Once the presence of tetrasporophytes of A. armata in the samples was confirmed, the bottom area affected by this alga was photographed and filmed. Its extension was detected by SCUBA diving and then measured by the use of satellite imagery (Google Earth) and the GIS program Manifold $^{\circledR}$.

Additionally, during low tide periods, the mediolittoral belt along the whole coastline of the Bay of Piran was visually surveyed from the land, and additional thalli of $A$. armata were collected from October 2016 to January 2017 (Fig. 1, sampling sites B-F). Bottom areas covered by $A$. armata were photographed and their extension was again measured by the use of satellite imagery (Google Earth) and the GIS program Manifold ${ }^{\circledR}$.

\section{RESULTS}

In front of the town of Piran (Fig. 1, sampling site A), at $1 \mathrm{~m}$ of depth the hard substrata composed by limestone boulders were mostly colonized by the red alga Corallina officinalis Linnaeus (Table 1). Its calcified thalli were densely overgrown by the tetrasporophyte of A. armata (Fig. 2). Both species were covering

Table 1. Macroalgal cover (\%) within a sampling frame of $20 \mathrm{~cm} \times 20 \mathrm{~cm}$ collected at $1 \mathrm{~m}, 2 \mathrm{~m}$ and $3 \mathrm{~m}$ of depth, at the sampling site $A$ in front of the town of Piran

\begin{tabular}{llcccc} 
& & Depth (m) & $\mathbf{1}$ & $\mathbf{2}$ & $\mathbf{3}$ \\
\hline Class & Taxa & $\begin{array}{c}\text { Functional } \\
\text { Group }\end{array}$ & & & \\
\hline Phaeophyceae & Cystoseira compressa & IA & 0 & 0 & $\mathbf{4}$ \\
Phaeophyceae & Padina pavonica & IB & 0 & 0 & $\mathbf{1 5}$ \\
Phaeophyceae & Dictyota dichotoma & IIA & 0 & $\mathbf{1 0}$ & $\mathbf{5}$ \\
Phaeophyceae & Halopteris scoparia & IIA & $\mathbf{1}$ & $\mathbf{4}$ & 0 \\
Florideophyceae & Jania virgata & IC & $\mathbf{3}$ & $\mathbf{8}$ & $\mathbf{1 2}$ \\
Florideophyceae & Corallina officinalis & IC & $\mathbf{6 0}$ & $\mathbf{4 3}$ & $\mathbf{4 8}$ \\
Florideophyceae & Peyssonnelia squamaria & IC & 0 & $\mathbf{6}$ & $\mathbf{8}$ \\
Florideophyceae & Asparagopsis armata & IIA & $\mathbf{6 0}$ & $\mathbf{1}$ & $\mathbf{1}$ \\
Florideophyceae & Ceramium spp. & IIB & 0 & 0 & $\mathbf{2}$ \\
Ulvophyceae & Cladophora spp. & IIB & 0 & 0 & $\mathbf{2}$
\end{tabular}




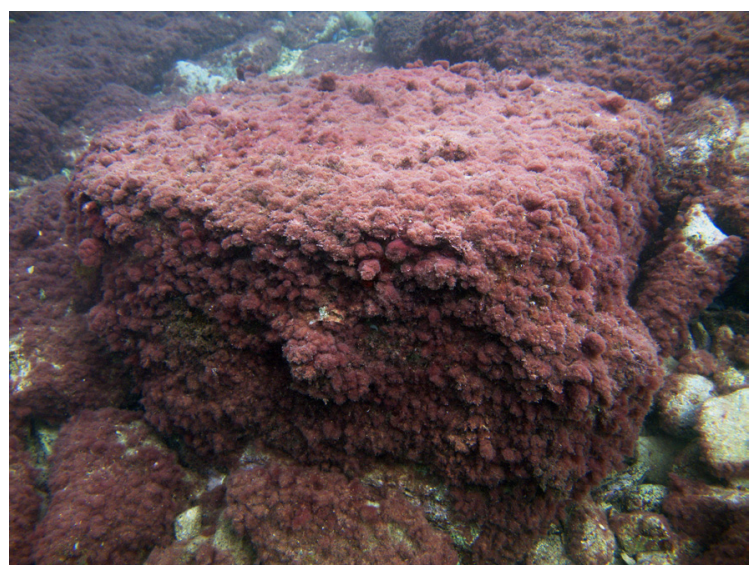

Fig. 2. Dense coverage of tetrasporophytes of A. armata in the Bay of Piran. They developed as ephyphytes on the red alga Corallina officinalis (photo: L. Lipej)

$60 \%$ of the surface of the sampling frame. At $2 \mathrm{~m}$ depth, C. officinalis covered $43 \%$ of the frame surface, while A. armata only $1 \%$. At 3 m depth $C$. officinalis covered $48 \%$ of the sampling frame surface, while $A$. armata again only $1 \%$ of it. At the site $\mathrm{A}$, the extension of the area covered by the tetrasporophyte of $A$. armata belt was estimated to be about $994 \mathrm{~m}^{2}$ (Table 2).

Along the coastline of the Piran Bay, the tetrasporophyte of $A$. armata was found to overgrow thalli of $C$. officinalis in the mediolittoral belt (depth down to $1.0 \mathrm{~m}$ ) at five other locations, where the hard substrata consist of limestone boulders, as well. The second largest patch of A. armata was recorded as site D, covering an area of approximately $403 \mathrm{~m}^{2}$, while the smallest was the patch E, covering around 20 $\mathrm{m}^{2}$ (Table 2).
At all sites the cover of the tetrasporophyte of $A$. armata drastically decreased in the second half of December 2016, and only thalli of C. officinalis remained. Eventually, in January 2017 A. armata disappeared completely from the mediolittoral belt of the Bay of Piran.

\section{DISCUSSION}

Due to its strong invasive behavior, A. arma$t a$ is included in the list of the "Worst invasive alien species threatening biodiversity in Europe" and also in the list of the "100 Worst Invasives in the Mediterranean Sea", without specifying whether the gametophyte or the tetrasporophyte is considered invasive (STREFTARIS \& ZENETOS, 2006). OTERO et al. (2013) reported that the genus Asparagoposis as a whole appears to have a high invasive potential, and that once $A$. armata becomes invasive, eradication and even control are almost impossible. Tetrasporophytes of $A$. armata are known to have a negative impact on the survival of native algal taxa, since they densely overgrow their host macrophytes (such as thalli of C. officinalis in the Bay of Piran), consequently decreasing the light irradiance available for these species (KATSANEVAKIS et al., 2014). Moreover, these tetrasporophytes are avoided by Mediterranean herbivores, since they are highly toxic both in summer and winter (MARTí et al., 2004). The results of ecotoxicological experiments with a gastropod mollusc, Gibbula umbilicalis (da Costa, 1778), as test organism, showed that A. armata exudates sig-

Table 2. Coordinates, length of the coastal segments and areas densely covered by tetrasporophytes of A. armata at sampling sites in the Bay of Piran

\section{Sampling site Longitude (E) Latitude (N)}

\begin{tabular}{ccccc}
\hline A & $13^{\circ} 33.983$ & $45^{\circ} 31.675$ & 121.44 & 993.76 \\
B & $13^{\circ} 34.002$ & $45^{\circ} 31.417$ & 14.51 & 47.36 \\
C & $13^{\circ} 34.058$ & $45^{\circ} 31.155$ & 12.67 & 29.41 \\
D & $13^{\circ} 34.245$ & $45^{\circ} 30.925$ & 87.11 & 402.78 \\
E & $13^{\circ} 34.282$ & $45^{\circ} 30.879$ & 6.20 & 20.26 \\
F & $13^{\circ} 34.292$ & $45^{\circ} 30.868$ & 31.07 & 164.69 \\
\hline
\end{tabular}

Length of the coastal segment (m)

Area covered $\left(\mathrm{m}^{2}\right)$

pling sites in the Bay of Piran 
nificantly affect the survival of this mollusc, without specifying whether they used the gametophyte or the tetrasporophyte of the alga (DA CRUZ JACINTO, 2015).

According to OZA (1989), on the European Mediterranean coasts water temperature and day length are in the favourable range for the growth of tetrasporophytes of $A$. armata, mainly in November and December. The photoperiod results too long for their growth before October, and again from January onwards, when also water temperatures are reported to be too low for the survival of thalli (OZA, 1989). However, the presence of the species in the northernmost part of the Mediterranean Sea has been very limited and sporadic in the last two decades, even in November and December. Our data collected in the Bay of Piran suggest that some environmental factors have changed in order to lead to the first recorded bloom of this red alga in the northern Adriatic Sea. Nevertheless, seabottom physical characteristics didn't change in the Bay of Piran in the last few years. According to the EEI-c methodology (ORFANIDIS et al., 2011), A. armata belongs to the functional group of opportunistic species (ESG II). Its high coverage at $1 \mathrm{~m}$ of depth in the bay of Piran, with the coexistence of the late-successional species (ESG I), indicates intermediate environmental conditions. Some researchers concluded that disturbance (especially trophic) is an important triggering factor that leads to the invasiveness of non-indigenous species (SCHAFFELKE \& HEWITT, 2007; TSIAMIS et al., 2013). However, the Slovenian national monitoring program of macrophytes in the upper-infralittoral belt has never revealed local pollution sources in the coastal area of the Piran town (ORLANDO-BONACA et al., 2008; unpublished monitoring data). Moreover, recent studies concerning the reduction of chlorophyll $a$ concentrations in the northern Adriatic, consistent with the decrease in phosphate and ammonia concentrations, highlighted the oligotrophication of the basin over the last decade (MOZETIČ et al., 2010, 2012). At the moment it is therefore impossible to formulate any valid hypothesis about the factors responsible for the considerable development of these tetrasporophytes in the area.
Since gametophytes $A$. armata are confirmed to be abundant in several Mediterranean marine areas (VERLAQUE et al., 2015), many researchers have tried to assess not only the impact of the species (both gametophytes and tetrasporophyetes) on the marine environment, but also any possible utility in terms of ecosystem services. In NW France they started to extract bioactive substances (for cosmetic and medical products) from cultivated, vegetatively propagated gametophytes in the mid 1990s (KRAAN \& BARRINGTON, 2005). Moreover, farming of gametophytes $A$. armata started also in Ireland by the end of the 1990s, since it was confirmed that the species produces biologically active secondary metabolites that are valuable natural medical ingredients, having antibacterial and antifungal activity (STEINBERG et al., 2001; KRAAN \& BARRINGTON 2005; PAUL et al., 2006; SALVADOR et al., 2007). Additionally, SCHUENHOFF et al. (2006) reported that tetrasporophytes of $A$. armata were successfully tank-cultivated as a continuous biofilter for the effluent of a commercial fish farm in southern Portugal. Tanks with these tetrasporophytes proved to be more efficient biofilters for effluents from a fish farm than the conventionally used Ulva rigida (MATA et al., 2010).

The sites affected by the massive spread of tetrasporophytes of A. armata in the Bay of Piran have to be regularly monitored in the future, in order to produce long-term datasets that can be used to formulate proper conclusions on the status of this NIS species in the coastal area concerned. Additionally, any changes in environmental factors have to be studied to point out which are responsible for the recent spread of the species. At the same time, new visual surveys should be conducted in other northern Adriatic areas. If tetrasporophytes of $A$. armata will become abundant in the northern Adriatic basin, the already verified possibility of its exploitation should be taken into consideration, and the ratio between the impact and the benefit for the local environment should be assessed. 


\section{ACKNOWLEDGEMENTS}

The authors would like to express their gratitude to the municipality of the town of Piran for their support during the study, to Tihomir MAKOVEC for his help during the field work, and to Milijan ŠIŠKO for the preparation of Figure 1 . Special thanks are due to two anonymous referees for constructive comments.

The authors acknowledge the financial support from the Slovenian Research Agency (research core funding No. P1-0237).

\section{REFERENCES}

ANDREAKIS, N., W.H.C.F. KOOISTRA \& G. PROCACCINI. 2009. High genetic diversity and connectivity in the polyploid invasive seaweed Asparagopsis taxiformis (Bonnemaisoniales) in the Mediterranean, explored with microsatellite alleles and multilocus genotypes. Molecular Ecology, 18: 212-226.

ANDREAKIS, N. \& B. SCHAFFELKE. 2012. Invasive marine seaweeds: pest or prize? In: $\mathrm{C}$. Wiencke \& K. Bischof (Editors). Seaweed biology. Springer, New York, pp. 235-262.

ANTOLIĆ, B., A. ŠPAN, A. ŽULJEVIĆ, V. NIKOLIĆ, I. GRUBELIĆ, M. DESPALATOVIĆ \& I. CVITKOVIĆ. 2013. A checklist of the benthic marine macroalgae from the eastern Adriatic coast: IV. Rhodophyta 2: Ceramiales excluded. Acta Adriatica, 54(1): 44-66.

BATTELLI, C. 2000, Priročnik za spoznavanje morske flore Tržaškega zaliva (Manual for the determination of the marine flora of the Gulf of Trieste). Institute for Education of the Republic of Slovenia, Ljubljana, $170 \mathrm{pp}$. BONIN, D.R. \& M.W. HAWKES. 1987. Systematics and life histories of New Zealand Bonnemaisoniaceae (Bonnemaisoniales, Rhodophyta): I. The genus Asparagopsis. N. Z. J. Bot., 25: 577-590.

BOUDOURESQUE, C.F. \& M. VERLAQUE. 2002. Biological pollution in the Mediterranean Sea: invasive versus introduced macrophytes. Mar. Pollut. Bull., 44: 32 - 38.

CHIHARA, M. 1961. Life cycle of the bonnemaissoniaceous algae in Japan (1). Science Republic Tokyo Kyoiku Daigaku, Section B, 10: 121-153.

CORSINI-FOKA, M., A. ZENETOS, F. CROCETTA, M.E. ÇINAR, F. KOÇAK, D. GOLANI, S. KATSANEVAKIS, K. TSIAMIS, E. COOK, C. FROGLIA, M. TRIANDAPHYLLOU, S. LAKKIS, G. KONDYLA-
TOS, E. TRICARICO, A. ŽULJEVIĆ, M. ALMEIDA, F. CARDIGOS, S. ÇAĞLAR, F. DURUCAN, A.M.D. FERNANDES, J. FERRARIO, I. HABERLE, P. LOUIZIDOU, J. MAKRIS, M. MARIĆ, D. MICU, C. MIFSUD, C. NALL, E. KYTINOU, D. POURSANIDIS, D. SPIGOLI, G. STASOLLA, S. YAPICI \& H.E. ROY. 2015. Inventory of alien and cryptogenic species of the Dodecanese (Aegean Sea, Greece): collaboration through COST action training school. Manag. Biol. Invasion., 6(4): 251-366.

DA CRUZ JACINTO, M. S. 2015. Impact of the invasive macroalgae Asparagopsis armata - an ecotoxicological assessment. Master's Dissertation Thesis, Instituto Politécnico de Leiria, URL: http://www.rcaap.pt/detail. jsp?id=oai:iconline.ipleiria.pt:10400.8/2179 DIXON, P.S. \& L.M. IRVINE. 1977. Seaweeds of the British Isles Vol.1 Rhodophyta Part 1 Introduction, Nemaliales, Gigartinales. British Museum (Natural History Museum, London. EUROPEAN COMMISSION. 2002. Convention on Biological Diversity definitions from COP VI/23. Sixth Meeting on the Conference of the Parties to the Convention on Biological Diversity. Netherlends.

FELDMANN, J. \& G. FELDMANN. 1942. Récherches sur les Bonnemaisoniacées et leur alternances de générations. Ann. Sci. Nat. Bot., II(3): $75-175$.

GALIL, B.S., 2009. Taking stock: inventory of alien species in the Mediterranean sea. Biol. Invasions, 11, 359-372.

GALIL, B.S., A. MARCHINI, A. OCCHIPINTI-AMBROGI, D. MINCHIN, A. NARŠČIUS, H. OJAVEER \& S. OLENIN. 2014. International arrivals: widespread bioinvasions in European seas. Ethol Ecol Evol, 26(2-3): 152-171. 
GOLLASCH, S. \& E. LEPPÄKOSKI. 1999. Initial Risk Assessment of Alien Species in Nordic Coastal Waters. In: S. Gollasch \& E. Leppäkoski (Editors). Initial Risk Assessment of Alien Species in Nordic Coastal Waters. Nordic Council of Ministers, Copenhagen, pp. 1-124.

GUIRY, M.D. \& C.J. DAWES. 1992. Daylength, temperature and nutrient control of tetrasporogenesis in Asparagopsis armata (Rhodophyta). J. Exp. Mar. Biol. Ecol., 158: 197-217.

HORRIDGE, G.A. 1951. Occurrence of Asparagopsis armata Harvey on the Scilly Isles. Nature, 167: 732 - 733.

KATSANEVAKIS, S., I. WALLENTINUS, A. ZENETOS, E. LEPPÄKOSKI, M.E. ÇINAR, B. OZTÜRK, M. GRABOWSKI, D. GOLANI \& A.C. CARDOSO. 2014. Impacts of invasive alien marine species on ecosystem services and biodiversity: a pan-European review. Aquat. Invasions, 9: 391-423.

KRAAN, S. \& K.A. BARRINGTON. 2005. Commercial farming of Asparagopsis armata (Bonnemaisoniceae, Rhodophyta) in Ireland, maintenance of an introduced species? Journal of Applied Phycology, 17(2): 103-110.

LIPEJ, L., B. MAVRIČ, M. ORLANDO-BONACA \& A. MALEJ. 2012. State of the art of the marine non-idigenous flora and fauna in Slovenia. Mediterranean Marine Science, 13: 243-249.

MAČIĆ, V., D. LUČIĆ, B. GANGAI ZOVKO, M. MANDIĆ, J. DULČIĆ, A. ŽULJEVIĆ, S. PETOVIĆ, D. DRAKULOVIĆ, M. MILOSLAVIĆ, I. ONOFRI, O. MARKOVIĆ, A. JOKSIMOVIĆ, V. ONOFRI \& B., PESTORIĆ. 2014. Monografija - Alohtone vrste istočne obale južnog Jadrana. Kratki pregled vrsta i ekologije. Institut za biologiju mora Univerziteta Crne Gore, Institut za more i priobalje Sveučilišta u Dubrovniku. Kotor, 64 pp.

MARTÍ, R., M.J. URIZ \& X. TURON. 2004. Seasonal and spatial variation of species toxicity in Mediterranean seaweed communities: correlation to biotic and abiotic factors. Marine Ecology Progress Series, 282: 73-85.

MATA, L., A. SCHUENHOFF \& R. SANTOS. 2010. A direct comparison of the seaweed biofilters, Asparagopsis armata and Ulva rigida. Jour- nal of Applied Phycology, 22(5): 639-644.

MICAEL, J., M.I. PARENTE \& A.C. COSTA. 2014. Tracking macroalgae introductions in North Atlantic oceanic islands. Helgoland Mar. Res., 68(2): 209-219.

MOZETIČ, P., C. SOLIDORO, G. COSSARINI, G. SOCAL, R. PRECALI, J. FRANCÉ, F. BIANCHI, C. DE VITTOR, N. SMODLAKA \& S. FONDA UMANI. 2010. Recent trends towards oligotrophication of the northern Adriatic: evidence from chlorophyll a time series. Estuaries and Coasts, 33: 362-375.

MOZETIČ, P., J. FRANCÉ, T. KOGOVŠEK, I. TALABER \& A. MALEJ. 2012. Plankton trends and community changes in a coastal sea (northern Adriatic): bottom-up vs. top-down control in relation to environmental drivers. Estuarine, coastal and shelf sci., 115: 138-148.

Ní CHUALÁIN, F., C.A. MAGGS, G.W. SAUNDERS \& M.D. GUIRY. 2004. The invasive genus Asparagopsis (Bonnemaisoniaceae, Rhodophyta): molecular systematics, morphology, and ecophysiology of Falkenbergia isolates. Journal of Phycology, 40: 1112-1126.

OGORELEC, B., J. FAGANELI, M. MIŠIČ \& B. ČERMELJ. 1997. Reconstruction of paleoenvironment in the Bay of Koper (Gulf of Trieste, Northern Adriatic). Annales, Series Historia Naturalis, 11: 187-200.

ORFANIDIS, S., P. PANAYOTIDIS \& K.I. UGLAND. 2011. Ecological Evaluation Index continuous formula (EEI-c) application: a step forward for functional groups, the formula and reference condition values. Mediterranean Marine Science, 12(1): 199-231.

ORLANDO-BONACA, M. 2001. A survey of the introduced non-indigenous species in the northern Adriatic Sea. Annales, Series Historia Naturalis, 11(2): 149-158.

ORLANDO-BONACA, M. 2010. New records on non-indigenous algal species in Slovenian coastal waters. Annales, Series Historia Naturalis, 20 (2): 143-150.

ORLANDO-BONACA, M., L. LIPEJ \& S. ORFANIDIS. 2008. Benthic macrophytes as a tool for delineating, monitoring and assessing ecological status: the case of Slovenian coastal waters. Marine Pollution Bulletin, 56 (4): 666-676. 
ORLANDO-BONACA, M., L. LIPEJ, A. MALEJ, J. FRANCÉ, B. ČERMELJ, O. BAJT, N. KOVAČ, B. MAVRIČ, V. TURK, P. MOZETIČ, A. RAMŠAK, T. KOGOVŠEK, M. ŠIŠKO, V. FLANDER-PUTRLE, $M$. GREGO, T. TINTA, B. PETELIN, M. VODOPIVEC, M. JEROMEL, U. MARTINČIČ \& V. MALAČIČ. 2012. Določanje dobrega okoljskega stanja. Poročilo za člen 9 Okvirne direktive o morski strategiji (Determination of Good Environmental Status. Report for article 9 of the Marine Strategy Framework Directive). Poročila MBP, 141 (Final national report in Slovenian, Marine Biology Station Piran, National Institute of Biology), $177 \mathrm{pp}$.

ORLANDO-BONACA, M., A. ŽULJEVIĆ \& B. ANTOLIĆ. 2016. Is the Port of Koper an inhospitable environment for the settlement of non-indigenous macrophytes? Annales, Series Historia Naturalis, 26(2): 225-232.

OTERO, M., E. CEBRIAN, P. FRANCOUR, B. GALIL \& D. SAVINI. 2013. Monitoring Marine Invasive Species in Mediterranean Marine Protected Areas (MPAs): A strategy and practical guide for managers. Malaga, Spain, IUCN, $136 \mathrm{pp}$.

OZA, R.M. 1989. Growth of red alga Falkenbergia rufolanosa (Harvey) Schmitz in response to temperature, irradiance and photoperiod. Indian Journal of Marine Sciences, 18: 210211.

PACIOS, I., J.M. GUERRA-GARCÍA, E. BAEZAROJANO \& M.P. CABEZAS. 2011. The nonnative seaweed Asparagopsis armata supports a diverse crustacean assemblage. Marine Environmental Research, 71: 275282.

PAUL, N.A., R. DE NYS \& P.D. STEINBERG. 2006. Chemical defence against bacteria in the red alga Asparagopsis armata: linking structure with function. Mar Ecol Prog Ser, 306: 87-101.

PRICE, J.H., D.M. JOHN \& G.M. LAWSON. 1986. Seaweeds of the western coast of tropical Africa and adjacent islands: a critical assessment IV. Rhodophyta (Florideae) 1. Genera A-F. Bull. Br. Mus. Nat. Hist. Bot. Ser., 15: 1 122.

RIBERA-SIGUAN, M.A. 2002. Review of non-native marine plants in the Mediterranean Sea.
In: E. Leppäkoski, S. Gollasch \& S. Olenin (Editors). Invasive aquatic species of Europe. Distribution, impacts and management. Kluwer Academic Publishers, Dordrech,. pp. 291-310.

RILOV, G. \& J.A. CROOKS. 2009. Biological invasions in marine ecosystems - ecological, management, and geographic perspectives. Springer, Berlin, 642 pp.

SALA, E. \& C.F. BOUDOURESQUE. 1997. The role of fishes in the organization of a Mediterranean sublittoral community. I: algal communities. J. Exp. Mar. Biol. Ecol., 212: 25 - 44.

SALVADOR, N., A. GÓMEZ GARRETA, L. LAVELLI \& M.A. RIBERA. 2007. Antimicrobial activity of Iberian macroalgae. Sci. Mar., 71(1): 101-113.

SCHAFFELKE, B. \& C.L. HEWITT. 2007. Impacts of introduced seaweeds. Botanica Marina, 50: 397-417.

SCHUENHOFF, A., L. MATA \& R. SANTOS. 2006. The tetrasporophyte of Asparagopsis armata as a novel seaweed biofilter. Aquaculture, 252: 3-11.

SOUTH, G.R. \& I. TITTLEY. 1986. A checklist and distributional index of the benthic marine algae of the North Atlantic Ocean. St. Andrews \& London, Huntsman Marine Laboratory \& British Museum (Natural History).

STAM, W., J. OLSEN, S.F. ZALESKI, S.N. MURRAY, K.R. BROWN \& L. WALTERS. 2006. A forensic and phylogenetic survey of Caulerpa species (Caulerpales, Chlorophyta) from the Florida coast, local aquarium shops, and e-commerce: establishing a proactive baseline for early detection. Journal of Phycology, 42: 1113-1124.

STEINBERG, P.D., R. DE NYS \& S. KJELLEBERG. 2001. Chemical mediation of surface colonization. In: J.B. McClintock \& B.J. Baker, (Editors). Marine Chemical Ecology. CRC Press, Boca Raton, pp. 355-387

STREFTARIS, N. \& A. ZENETOS. 2006. Alien Marine Species in the Mediterranean - the 100 'Worst Invasives' and their Impact. Mediterranean Marine Science, 7(1): 87-118.

TSIAMIS, K., P. PANAYOTIDIS \& A. ZENETOS. 2008. Alien marine macrophytes in Greece: a review. Botanica Marina, 51: 237-246. 
TSIAMIS, K., A. ECONOMOU-AMILLI, C. KATSAROS \& P. PANAYOTIDIS. 2013. First account of native and alien macroalgal biodiversity at Andros Island (Greece, Eastern Mediterranean). Nova Hedwigia, 97(1-2): 209 - 224.

VERLAQUE, M. 2001. Checklist of the macroalgae of Thau Lagoon (Herault, France), a hot spot of marine species introduction in Europe. Oceanol. Acta, 24: 29-49.

VERLAQUE, M., S. RUITTON, F. MINEUR \& C.-F. BOUDOURESQUE. 2015. F. Briand (Editor).
CIESM Atlas of Exotic Species in the Mediterranean - Vol. 4 Macrophytes. CIESM Publisher, Monaco, 364 pp.

ZANOLLA, M., R. CARMONA, J. DE LA ROSA, N. SALVADOR, A.R. SHERWOOD, N. ANDREAKIS \& M. ALTAMIRANO. 2014. Morphological differentiation of cryptic lineages within the invasive genus Asparagopsis (Bonnemaisoniales, Rhodophyta). Phycologia, 53 (3): 233-242.

Received: 12 January 2017

Accepted: 29 March 2017 


\title{
Neuobičajeno cvjetanje tetrasporofita nezavičajnih crvenih algi Asparagopsis armata na sjevernom Jadranu
}

\author{
Martina ORLANDO-BONACA*, Borut MAVRIČ, Domen TRKOV i Lovrenc LIPEJ
}

*Kontakt e-adresa: Martina.Orlando@nib.si

\section{SAŽETAK}

Tetrasporofite ne-autohtone crvene alge Asparagopsis armata (Falkenbergia faza) smatra se prisutnom u slovenskim obalnim vodama. Međutim, do 2016. godine, ustanovljena je isključivo mala pokrivenost $\mathrm{i}$ to na nekoliko lokaliteta s tvrdom podlogom (sediment). U ovom radu se navodi nedavni procvat tetrasoprofita u mezolitoralnom pojasu Piranskog zaljeva gdje je crvena alga $A$. armata nadjačala koraljnu algu Corallina officinalis.

U budućnosti će se redovito nadzirati mjesta na koja utječe ova velika ekspanzija tetrasporofita,

kako bi se istaknulo koji su ekološki čimbenici odgovorni za takav fenomen, te da bi se mogli formulirati odgovarajući zaključci o statusu ove ne-autohtone alge u tim obalnim područjima.

Ključne riječi: nezavičajne vrste, Asparagopsis armata, ekspanzija algi, tetrasporofite, sjeverni Jadran 